\title{
Determinants of mother to child transmission of HIV among HIV exposed infants managed in Usmanu Danfodiyo University Teaching Hospital, Sokoto, Nigeria
}

\author{
Hassan Mairo $^{1 *}$, Panti A. A. ${ }^{1}$, Tunau K. A. ${ }^{1}$, Nasir S. ${ }^{2}$, \\ Burodo A. T. ${ }^{1}$, Adamu N. A. ${ }^{2}$, Garba J. A. ${ }^{1}$
}

\begin{abstract}
${ }^{1}$ Department of Obstetrics and Gynecology, Usmanu Danfodiyo University Teaching Hospital, Sokoto, Nigeria
${ }^{2}$ National Obstetrics Fistula Centre, Babbar Ruga, Katsina State, Nigeria

${ }^{3}$ Department of Obstetrics and Gynecology, Federal Medical Centre, Birnin Kebbi, Kebbi State, Nigeria
\end{abstract}

Received: 09 August 2018

Accepted: 04 September 2018

\author{
*Correspondence: \\ Dr. Hassan Mairo, \\ E-mail: mayroh123@gmail.com
}

Copyright: $($ ) the author(s), publisher and licensee Medip Academy. This is an open-access article distributed under the terms of the Creative Commons Attribution Non-Commercial License, which permits unrestricted non-commercial use, distribution, and reproduction in any medium, provided the original work is properly cited.

\begin{abstract}
Background: Mother to child transmission of HIV (MTCT) is globally known to be the major route of spread of HIV to the unborn fetus and neonate. Many factors related to the mother, infant or the type of HIV virus interplay to increase the risk of MTCT of the virus. Antepartum antiretroviral drugs administration reduces the maternal viral load therefore lowering the risk of transmission. The objective is to determine infection rate and assess determinants of MTCT of HIV exposed infants delivered in UDUTH Sokoto.

Methods: It was a 5-year retrospective study. Records of all HIV positive pregnant women and their babies managed in UDUTH were reviewed from the E health system of the hospital. Patient's details were recorded from booking to delivery for the period under study. The infant's records were retrieved and information from delivery to 18 months post-delivery obtained. Structured data collection tool was developed to compile the required information. Data was analyzed using SPSS IBMS 22. Descriptive statistics and comparisons between variables were made statistically using Chi square. $\mathrm{P}$ value of $\leq 0.005$ was considered as significant.

Results: Records of all the patients recruited were all available for evaluation because authors use the E-health system of records keeping in our hospital. MTCT rate was $0.92 \%$. Majority 60 (47.2\%) were within age group 26-30yrs. The subjects were predominantly house wives $97(71.4 \%)$ and multipara $77(60.6 \%)$. Viral load ranged between 112 to 28228 copies/ml. Twenty-two $(17.3 \%)$ had CD4 count less than 250 cells/ $\mu$ l while $61(48 \%)$ had counts above 500cells $/ \mu 1$. All were in WHO clinical stage 1-3. All were on triple regimen anti-retroviral drugs. Spontaneous rupture of membranes for over 4 hours occurred in 51(32\%). Vaginal delivery was recorded in $89.7 \%$. Breast feeding was practiced by $48 \%$.
\end{abstract}

Conclusions: Breast-feeding still remains a risk factor for MTCT OF HIV Early administration of maternal antiretroviral drugs significantly reduces the rate of mother to child transmission of HIV.

Keywords: HIV, PMTCT, Risk factors

\section{INTRODUCTION}

Human immune deficiency virus (HIV) is an important public health problem in our environment. Mother to child transmission of HIV (MTCT) is globally known to be the major route of spread of HIV to the unborn fetus. ${ }^{1}$ A great deal is known about specific factors that may predispose a woman to be at higher risk of transmitting 
the HIV virus to her baby. These factors may be related to the mother, infant or the type of HIV virus. These risk factors may be present during pregnancy, labour, delivery breast feeding. The mechanisms of MTCT, however, are multifactorial and may involve interplay within these factors. Some of the factors that determines transmission of the infection from mother to her unborn child includes, high maternal viral load, absence of anti-retroviral drugs therapy, viral, bacterial or parasitic placental infection, rupture of membranes greater than 4 hours during labour, prolonged labour, invasive delivery procedures, duration of breast feeding, breast abscess or cracked nipples. ${ }^{2}$

Maternal viral load is an important determinant of MTCT. The risk of transmission to the baby is greatest when the maternal viral load is high. Rate of transmission is low when the infected mother receives potent antiretroviral therapy or when the mother's plasma HIV RNA level is below assay detection limits but can be as high as $50 \%$ in women with high HIVRNA levels who are receiving no antiretroviral therapy. ${ }^{3}$ Although the placental entry of some infections is a critical aspect of these infections, the role of placental cells and the mechanism by which pathogens pass from the maternal to the fetal circulation varies. The placenta provides a barrier that prevents transmission of some viruses but allows others to reach the fetal circulation. Mother to fetus placental transmission of some viruses occurs through transcytosis across placental cells. The placenta may also act as a reservoir in which virus replicates before reaching the fetus. Vertical transmission of HIV may occur through CD4 endothelial tissues or CD4 Hofbauer cells. Trophoblasts and villi have CD4 receptors, which make them potential candidates for HIV infection. Genetic analysis of HIV-1 sequences verify the interaction of HIV-1 and placental tissue. ${ }^{4}$

Rupture of membranes increases fetal exposure to maternal blood and vaginal fluids, and prolonged duration of rupture of membranes has been shown to be a significant risk factor for vertical transmission. ${ }^{5}$ Evidence exists that after 4 hours of rupture of membranes the risk of MTCT rises and the protective effect of a cesarean section is lost. ${ }^{5-7}$ However, these conclusions were based on studies in which only intrapartum monotherapy with Zidovudine was used and maternal viral load was not known. Since the addition of highly active antiretroviral drugs, subsequent research has been performed to determine if prolonged duration of rupture of membranes remains an important risk factor for vertical transmission.

Most studies agree that the risk of transmission is higher during labor and delivery compared to during pregnancy or via breastfeeding. Prolonged labour increases the risk of mother to child transmission of the virus. ${ }^{8}$ Transmission of HIV through breast milk is of concern in sub-Saharan African countries where HIV infection in women is common and breastfeeding is the accepted mode of infant feeding practiced. It is estimated that breastfeeding increases the overall risk of MTCT by $14 \%$ for women with established HIV infection and by $29 \%$ for women who become infected during lactation. ${ }^{9}$ Data from a randomized controlled trial in which mothers were allocated to either breastfeeding or artificial feeding confirmed an additional absolute risk of vertical transmission through breastfeeding of $16 \%$ when followup was conducted after two years. In this trial, breastfeeding approximately doubled the overall rate of transmission. ${ }^{10}$

The aim of this study is to determine the infection rate and assess the determinants of mother-to-child HIV Transmission in HIV exposed infants delivered in Usmanu Danfodiyo University Teaching Hospital Sokoto.

\section{METHODS}

The study was a 5-year retrospective study. Involving all pregnant mothers diagnosed to be HIV positive between $1^{\text {st }}$ January 2012 to $31^{\text {st }}$ December 2016. The inclusion criteria were all HIV positive pregnant women who had antenatal care, PMTCT intervention and delivered in Usmanu Danfodiyo University Teaching Hospital during the study period. It also included all neonates that were HIV exposed and delivered in the same hospital by the recruited women. The patient's details were obtained from booking to delivery for the period under study from the hospital Electronic health records. The neonates' records were also retrieved and information from delivery to 18 months post-delivery were recorded. A structured data collection tool was developed to compile the required information. Information obtained included the socio demographic data, Gestational age at booking CD4, Viral load, mode of delivery duration of membrane rupture before delivery. According to the national HIVexposed infant care guideline, HIV diagnosis of exposed infants was made by a positive virological test using Deoxyribonucleic Acid-Polymerase Chain Reaction (DNA-PCR) test at 6 weeks and 18 months. The results of the two tests were obtained from their records. The mode of infant feeding was also recorded.

\section{Statistical analysis}

Data was analyzed using SPSS IBMS version 22. Descriptive statistics and comparisons between variables were made statistically using Chi square. $P$ value of $\leq 0.005$ was considered as significant in all statistical comparisons.

\section{RESULTS}

During the period of study, there were 13,735 deliveries out of which 127 were in the prevention of mother to child transmission of HIV (PMTCT) program, giving a prevalence of $0.92 \%$. The maternal age ranged between 15 to 40 years however majority $60(47.2 \%)$ were within the age group 26-30 years. Most were Hausa/ Fulani and Muslims. The subjects were predominantly house wives 
$97(71.4 \%)$ and multipara $77(60.6 \%)$. Only $91(71.7 \%)$ patients were able to have their viral load tested during the period of the study due to occasional malfunctioning of the PCR machine. The viral load of the patients ranged between 112 to 28228 copies/ml. About 49 (55.8\%) had more than 1000 viral copies while $42(49.2 \%)$ had less than 1000 copies/ml. All the pregnant women recruited were on triple regimen anti-retroviral drugs. Antiretroviral drugs were commenced before pregnancy in 17 (13.4\%) and during pregnancy in 110 (86.6\%). Neonatal birth weight ranged between 1.75 to $4.3 \mathrm{~kg}$.

Table 1: Sociodemographic characteristics of the respondents.

\begin{tabular}{|lll|}
\hline Characteristics & $\mathbf{N}=\mathbf{1 2 7}$ & $\%$ \\
\hline Age & 6 & 4.7 \\
\hline $15-20$ & 30 & 23.6 \\
\hline $21-25$ & 60 & 47.2 \\
\hline $26-30$ & 26 & 20.5 \\
\hline $31-35$ & 4 & 3.1 \\
\hline $36-40$ & 1 & 0.8 \\
\hline Above 40 & & \\
\hline Ethnicity & 65 & 51.2 \\
\hline Hausa/ Fulani & 26 & 20.5 \\
\hline Igbo & 6 & 4.7 \\
\hline Yoruba & 30 & 23.6 \\
\hline Others & & \\
\hline Religion & 78 & 61.4 \\
\hline Islam & 49 & 38.6 \\
\hline Christianity & & \\
\hline Occupation & 97 & 76.4 \\
\hline House wife & 15 & 11.8 \\
\hline Civil servant & 8 & 6.3 \\
\hline Trader & 7 & 5.5 \\
\hline Student & & 7 \\
\hline Parity & 9 & 28.3 \\
\hline Nullipara & 36 & 60.6 \\
\hline Primipara & 77 & 4 \\
\hline Multipara & 5 & \\
\hline Grandmultipara & & \\
\hline & & \\
\hline
\end{tabular}

A total of $106(83.5 \%)$ women booked for antenatal care during the first and second trimester of their pregnancy benefitting of enough time for viral suppression with antiretroviral drugs. Their CD4 count ranged between 39 to1132 cells/ $\mu 1$ however $22(17.3 \%)$ had CD4 count less than 250 cells $/ \mu 1$ while $61(48 \%)$ had counts above 500 cells. Most of the mothers had vaginal delivery because they benefited from anti-retroviral drugs and other PMTCT interventions and had no contraindication for vaginal delivery. Spontaneous rupture of membranes for over 4 hours occurred in 51(32\%) mostly due to delay in presenting to the hospital and in few delay in preparation for caesarean section.

A total of 13 babies tested positive at 6 weeks. The CD4 of their mothers were noted to be below 500 cell $/ \mu 1$ in 10 of them $(43.2 \%)$ and above 500 cells/ $\mu 1$ in 3 women. By
18 months PCR showed that an additional 7 neonates delivered by mothers whose CD4 count was less than 250 cells/ $\mu 1$ tested PCR positive increasing the number of PCR positive neonates to 16 .

Table 2: Determinant of mother to child transmission of HIV.

\begin{tabular}{|c|c|c|}
\hline Characteristics & $\mathrm{N}=127$ & $\%$ \\
\hline \multicolumn{3}{|c|}{ Gestational age at booking } \\
\hline $1^{\text {st }}$ trimester & 23 & 18.1 \\
\hline $2^{\text {nd }}$ trimester & 83 & 65.4 \\
\hline $3^{\text {rd }}$ trimester & 21 & 16.5 \\
\hline \multicolumn{3}{|l|}{ Mode of delivery } \\
\hline Vaginal & 114 & 89.7 \\
\hline $\mathrm{CS}$ & 10 & 7.8 \\
\hline Abortion & 3 & 2.4 \\
\hline \multicolumn{3}{|c|}{ Maternal CD4 count at booking } \\
\hline$<250$ & 22 & 17.3 \\
\hline $250-499$ & 44 & 34.6 \\
\hline 500 and above & 61 & 48.0 \\
\hline \multicolumn{3}{|c|}{ Duration of membrane rupture } \\
\hline Less than 4 hours & 76 & 66.0 \\
\hline 4 hours and above & 51 & 32.0 \\
\hline \multicolumn{3}{|c|}{ Mode of infant feeding } \\
\hline Breast feeding & 62 & 48 \\
\hline Infant formula & 65 & 51 \\
\hline
\end{tabular}

This could probably be due to the effect of breast feeding which is the preferred mode of feeding in this environment. A very significant statistical significance was noted between maternal CD4 and PCR results at 6 weeks and 18 months with more neonates being positive in mothers with CD4 counts less than 250cells/ $\mu 1$ $\mathrm{P} \leq 0.001$. All the women were in WHO clinical stages 1 to 3 . None was in stage 4 . Majority were asymptomatic (clinical stage 1) although 6 of the subjects were in stage 3.

Table 3: Comparison of CD4 count and PCR.

\begin{tabular}{|c|c|c|c|c|}
\hline \multicolumn{5}{|c|}{ Comparison of CD4 count and PCR at 6 weeks } \\
\hline $\begin{array}{l}\text { CD4 } \\
\text { count }\end{array}$ & $\begin{array}{l}\text { PCR } \\
\text { Positive } \\
\text { n (\%) }\end{array}$ & $\begin{array}{l}\text { PCR } \\
\text { Negative } \\
\text { n }(\%)\end{array}$ & $\begin{array}{l}\chi^{2} / \\
\text { Fischer } \\
\text { exact }\end{array}$ & $\begin{array}{l}P \\
\text { value }\end{array}$ \\
\hline $\begin{array}{l}\leq 250 \\
\text { cells/mcrl }\end{array}$ & $9(40.9)$ & $13(59.1)$ & \multirow{3}{*}{19.746} & \multirow{3}{*}{0.001} \\
\hline $\begin{array}{l}250-499 \\
\text { cells }\end{array}$ & $1(2.3)$ & $43(97.7)$ & & \\
\hline $\begin{array}{l}500 \text { and } \\
\text { above }\end{array}$ & $3(4.9)$ & $58(95.1)$ & & \\
\hline \multicolumn{5}{|c|}{ Comparison of CD4 count and PCR at 18 months } \\
\hline $\begin{array}{l}<250 \\
\text { cells/mcrl }\end{array}$ & $16(72.7)$ & $6(27.3)$ & \multirow{3}{*}{65.247} & \multirow{3}{*}{$<0.001$} \\
\hline $\begin{array}{l}250-499 \\
\text { cells }\end{array}$ & $1(2.3)$ & $43(97.7)$ & & \\
\hline $\begin{array}{l}500 \text { and } \\
\text { above }\end{array}$ & $3(4.9)$ & $58(95.1)$ & & \\
\hline
\end{tabular}


Even though most of the neonates were delivered by women in stage 1 , there was a very significant statistical association between maternal WHO clinical staging and rate of infection at 6 weeks and 18 months $\mathrm{P} \leq 0.001$.

Table 4: WHO clinical staging and PCR.

\begin{tabular}{|c|c|c|c|c|}
\hline \multicolumn{5}{|c|}{ Clinical staging and PCR at 6 weeks } \\
\hline Stage & $\begin{array}{l}\text { PRC } \\
\text { Positive } \\
\text { n }(\%)\end{array}$ & $\begin{array}{l}\text { PRC } \\
\text { Negative } \\
\text { n }(\%)\end{array}$ & $\begin{array}{l}\chi^{2} / \\
\text { Fischer } \\
\text { exact }\end{array}$ & $P$ value \\
\hline Stage 1 & $16(72.7)$ & $76(95.0)$ & \multirow{3}{*}{28.191} & \multirow{3}{*}{$<0.001$} \\
\hline Stage 2 & $1(2.3)$ & $18(85.7)$ & & \\
\hline Stage 3 & $6(100)$ & $0(0.0)$ & & \\
\hline \multicolumn{5}{|c|}{ Clinical staging and PCR at 18 months } \\
\hline Stage 1 & $8(10.0)$ & $72(90.0)$ & \multirow{4}{*}{24.016} & \multirow{4}{*}{$<0.001$} \\
\hline Stage 2 & $6(78.6)$ & $15(71.4)$ & & \\
\hline Stage 3 & $6(100.0)$ & $0(0)$ & & \\
\hline Total & $20(18.7)$ & $87(81.3)$ & & \\
\hline
\end{tabular}

More breastfed babies tested positive at 18 months in mothers in WHO clinical stage 2, however authors did not find any significant association when authors compared mode of infant feeding and PCR at 6 and 18 months.

Table 5: Comparison of mode of infant feeding and PCR.

\begin{tabular}{lllll|}
$\begin{array}{l}\text { Mode of feeding and PCR at } 6 \text { weeks } \\
\text { Mode of } \\
\text { feeding }\end{array}$ & $\begin{array}{l}\text { PCR } \\
\text { Positive } \\
\mathbf{n}(\%)\end{array}$ & $\begin{array}{l}\text { PCR } \\
\text { Negative } \\
\mathbf{n}(\%)\end{array}$ & $\begin{array}{l}\boldsymbol{\chi}^{2} / \\
\text { Fischer } \\
\text { exact }\end{array}$ & P value \\
$\begin{array}{l}\text { Breast } \\
\text { feeding }\end{array}$ & $6(8.3)$ & $66(84.7)$ & 0.28 & 0.418 \\
\hline $\begin{array}{l}\text { Infant } \\
\text { formula }\end{array}$ & $7(12.7)$ & $48(87.3)$ & & \\
$\begin{array}{l}\text { Mode of feeding and PCR at 18 months } \\
\text { Breast } \\
\text { feeding }\end{array}$ & $11(15.3)$ & $61(84.7)$ & 0.28 & 0.868 \\
\hline $\begin{array}{l}\text { Infant } \\
\text { formula }\end{array}$ & $9(16.4)$ & $46(83.6)$ & & \\
\hline
\end{tabular}

\section{DISCUSSION}

The prevalence of mother to child transmission of HIV in present study is $0.92 \%$. Transmission rate was 13 $(10.2 \%)$ and $20(15.7 \%)$ at 6 weeks and 18 months respectively. This finding is significantly lower than that reported in a study conducted in rural South Africa by Collins et al where the prevalence was $14 \%$ in infants younger than 6 weeks of age to $24 \%$ at 3-6 months. ${ }^{11}$ It was also less than that found in Cameroon which was $11.6 \% .^{12}$ The high prevalence in Cameroon was because Ninety-one-point one percent of infants and $65.2 \%$ of mothers did not receive ARV prophylaxis. However, our prevalence of $0.92 \%$ closely agrees with a similar study conducted in National Hospital Abuja, Nigeria, in which $1.3 \%$ prevalence was reported. ${ }^{13}$ This may be explained by the fact that all the pregnant women received antiretroviral drug in both studies.

Almost half of our patients had viral load above 1000copies $/ \mathrm{mL}$ indicating an increased risk of mother to child transmission. However, all the patients benefitted either from anti-retroviral prophylaxis or anti-retroviral treatment for their own disease along with other prevention of mother to child transmission of HIV (PMTCT) interventions? This could explain why authors recorded a lower transmission rate compared to other studies. Studies have shown that combination antiretroviral drugs to be associated with a larger reduction in risk of vertical transmission. ${ }^{14}$ Suppression of the maternal viral load to undetectable levels (below 50 copies $/ \mathrm{mL}$ ) using highly active antiretroviral therapy (HAART) offers the greatest risk reduction, and is currently the standard of care offered in most countries, where MTCT rates have been reduced to $1-2 \% .{ }^{15}$ The lowest CD4 count was 39 cells/ $\mu$ l while the highest was 1132 cells/ $\mu 1$. Out of the 127 women 66 of them had CD4 count below 500 cells/ $\mu$ l. Out of these 22 women had CD $4 \leq 250$ cells $/ \mu 1$. These were the group of mothers whose neonates were noted to have tested positive. This is comparable to similar findings of a European collaborative study that observed an association between transmission and low CD4 count. ${ }^{16}$ Similar observation was made in the study conducted in Jos in which $48.6 \%$ of their patients had CD4 count less than 200cell/ $\mu 1$ while in our study authors reported $51.8 \% .{ }^{17}$ This further highlights the association of maternal immune status and transmission of infection to the unborn child and neonate.

Rupture of fetal membranes (ROM) increases fetal exposure to maternal blood and vaginal fluids, and prolonged duration of ROM has been shown to be a significant risk factor for vertical transmission. Evidence exists that after 4 hours of ROM the risk of MTCT rises and the protective effect of a cesarean section is lost. However, these conclusions were based on studies in which only intrapartum monotherapy with ZDV was used and maternal viral load was not known. Since the addition of HAART, subsequent research has been performed to determine if prolonged duration of ROM remains an important risk factor for vertical transmission. These studies have demonstrated that there is no increased risk of transmission with ROM longer than 4 hours. ${ }^{18,19}$ In present study 51 (32\%) mothers had rupture of membranes for than 4 hours before delivery, however comparison did not reveal any statistically significant association between duration of membrane rupture and MTCT thereby agreeing with this finding. This result also agrees with similar study in Canada, UK and Ireland Enugu in which they found that Increasing the duration of ROM did not increase the likelihood of MTCT in their subjects. ${ }^{18,20,21}$ They found no statistical association between duration of ROM and MTCT in women taking antiretroviral drugs. Evidence suggests that mothers with established infection can transmit HIV infection through breast milk. ${ }^{2,16}$ Forty eight percent of the mothers in this 
study breast fed their neonates similar to that found in Abuja however this is lower than $61 \%$ found in southwestern Nigeria. ${ }^{13,22}$

\section{CONCLUSION}

Breast feeding which is the preferred and acceptable mode of infant feeding continues to be an important determinant of vertical transmission of HIV in our environment. Early administration of maternal antiretroviral drugs significantly reduces the rate of mother to child transmission of HIV by controlling the viral load. HIV positive mothers should be commenced on antiretroviral drugs as early as possible.

Funding: No funding sources

Conflict of interest: None declared

Ethical approval: The study was approved by the Institutional Ethics Committee

\section{REFERENCES}

1. Dube Q, Dow A, Chirambo C, Lebov J, Tentani L, Moore M, et al. Implementing early infant diagnosis of HIV infection at primary care level. Experiences and challenges in Malawi. Bull World Health Org. 2012; 90(9):699-704.

2. Federal Ministry of Health. National Guidelines for Prevention of mother to child transmission of HIV (PMTCT). Nigeria 2010.

3. Cooper ER, Charurat M, Mofenson L, Hanson IC, Pitt J, Diaz C, et al. Combination antiretroviral strategies for the treatment of pregnant HIV-1-infected women and prevention of perinatal HIV-1 transmission. JAIDSHagerstown MD. 2002;29(5):484-94.

4. Al-Husaini AM. Role of placenta in the vertical transmission of human. immunodeficiency virus. J Perinatol. 2009(29); 187: 331-6.

5. Garcia-Tejedor A, Perales A, Maiques V. Duration of ruptured membranes and extended labor are risk factors for HIV transmission. Int $\mathrm{J}$ Gynecol Obstet. 2003;82(1):17-23.

6. Mofenson LM. Prevention in neglected subpopulations: prevention of mother-to-child transmission of HIV infection. Clin Infect Dis. 2010;50(S3):S130-48.

7. Bulterys MB, Fowler MG, Hanson IC, Lemay M, Mayaux MJ, Mofenson L, et al. Duration of ruptured membranes and vertical transmission of HIV-1: a metaanalysis from 15 prospective cohort studies. Aids. 2001;15(3):357-68.

8. De Cock KM, Fowler MG, Mercier E, De Vincenzi I, Saba J, Hoff E, et al. Prevention of mother-to-child HIV transmission in resource-poor countries: translating research into policy and practice. Jama. 2000;283(9):1175-82.

9. Nduati R, John G, Mbori-Ngacha D, Richardson B, Overbaugh J, Mwatha A, et al. Effect of breastfeeding and formula feeding on transmission of HIV-1: a randomized clinical trial. Jama. 2000;283(9):1167-74.
10. Coutsoudis A, Pillay K, Kuhn L, Spooner E, Tsai WY, Coovadia HM, South African Vitamin A Study Group. Method of feeding and transmission of HIV-1 from mothers to children by 15 months of age: prospective cohort study from Durban, South Africa. Aids. 2001;15(3):379-87.

11. Rollins NC, Dedicoat M, Danaviah S, Page T, Bishop $\mathrm{K}$, Kleinschmidt I, et al. Prevalence, incidence, and mother-to-child transmission of HIV-1 in rural South Africa. Lancet. 2002;360:9330-89.

12. Noubiap JJ, Bongoe A, Demanou SA. Mother-to-child transmission of HIV: findings from an Early Infant Diagnosis program in Bertoua, Eastern Cameroon. Pan Afr Med J. 2013;15(1).

13. Chukwuemeka IK, Fatima MI, Ovavi ZK, Olukayode O. The impact of a HIV prevention of mother to child transmission program in a nigerian early infant diagnosis centre. Nigerian Med Assoc J. 2014;55(3):204-8.

14. Marie-Louise N. Prevention of mother-to-child transmission of HIV: challenges for the current decade. Bull World Health Org. 2001;79(12).

15. Jimmy AV. HIV: Mother-to-child transmission. BMJ Clin Evid. 2008;2008:0909.

16. Newell ML, Dunn D, Peckham CS, Ades AE, Pardi G, Semprini AE, et al. Risk factors for mother-to-child transmission of HIV-1. Int $\mathbf{J}$ Gynecol Obstet. 1992;39(4):357.

17. Charurat M, Datong P, Matawal B, Ajene A, Blattner $\mathrm{W}$, Abimiku AL. Timing and determinants of motherto-child transmission of HIV in Nigeria. Int $\mathbf{J}$ Gynecol Obstet. 2009;106(1):8-13.

18. Mark S, Murphy KE, Read S, Bitnun A, Yudin MH. HIV mother-to-child transmission, mode of delivery, and duration of rupture of membranes: experience in the current era. Infectious Dis Obstet Gynecol. 2012;2012.

19. Garcia-Tejedor A, Perales, A, Maiques V. Duration of ruptured membranes and extended labor are risk factors for HIV transmission. Int $\mathbf{J}$ Gynecol Obstet. 2003;1(82):17-23.

20. Peters H, Byrne L, De Ruiter A, Francis K, Harding K, Taylor GP, et al. Duration of ruptured membranes and mother-to-child HIV transmission: a prospective population-based surveillance study. BJOG. 2016;123(6):975-81.

21. Iloh KK, Iloh ON, Ikefuna AN, Ibeziako NS, Ubesi MPHAC, Emodi IJ. Determinants of mother-to-child transmission of HIV despite PMTCT interventions in Enugu, Nigeria. S Afr J Ch. 2015;9(2):49-52.

22. Usman A, Dairo D, Fawole O. Exclusive breastfeeding and HIV/AIDS: a crossectional survey of mothers attending prevention of mother-to-child transmission of HIV clinics in southwestern Nigeria. Pan Afr Med J. 2015; 21:309.

Cite this article as: Mairo H, Panti AA, Tunau KA, Nasir S, Burodo AT, Adamu NA, et al. Determinants of mother to child transmission of HIV among HIV exposed infants managed in Usmanu Danfodiyo University Teaching Hospital, Sokoto, Nigeria. Int J Reprod Contracept Obstet Gynecol 2018;7:4413-7. 